\title{
The effect of diet supplementation with propolis and bee pollen on the physicochemical properties and strength of tibial bones in broiler chickens
}

\author{
Katarzyna Kleczek', Katarzyna Majewska², Włodzimierz Makowski and Danuta \\ Michalik'
}

'Department of Commodity Science and Animal Improvement, Faculty of Animal Bioengineering, University of Warmia and Mazury, Poland, ${ }^{2}$ Chair of Food Plant Chemistry and Processing, Faculty of Food Sciences, University of Warmia and Mazury, Poland

\begin{abstract}
The objective of this study was to determine the effect of diet supplementation with propolis and bee pollen on selected physical, biomechanical and chemical properties of tibial bones in broiler chickens. The experimental materials comprised 384 Ross 308 chickens (four groups, three replications), divided into groups of males and females, and raised to 35 days of age. Control group 1 birds were fed a commercial diet throughout the experiment. Birds of three other experimental groups received for the first two weeks of rearing standard diets with a different content of propolis and/or bee pollen: group $2-0.025 \%$ propolis, group $3-0.5 \%$ bee pollen, group $4-0.5 \%$ bee pollen and $0.025 \%$ propolis. The following parameters of the tibia were determined: weight, length, mid-shaft circumference, vertical and horizontal external diameters, vertical and horizontal internal diameters. The geometric characteristics of the bones were determined based on the above measurements. Mid-shaft shear strength was measured using an Instron universal testing machine 4301 (Instron, Norwood, MA, USA). The crude ash, calcium ( $\mathrm{Ca}$ ) and phosphorus ( $\mathrm{P}$ ) content of the tibia was also determined. Higher values of geometric parameters were noted in the tibial bones of broilers fed a diet supplemented with a combination of propolis and bee pollen, in comparison with birds fed diets containing propolis or bee pollen administered alone. The shear strength values and physical properties of bones were similar in all groups.
\end{abstract}

Keywords: broiler chickens, propolis, bee pollen, bones, physical properties, bone strength, chemical composition

\section{Introduction}

Broiler chickens are characterized by a very fast growth rate, therefore broiler diets should contain high concentrations of available nutrients (Zimnoch et al. 2000). Until recently, antibiotics had been used to improve feed utilization efficiency in poultry, but after the ban imposed in the European Union they were replaced by natural feed additives, including herbs (Kwiecień \& Winiarska-Mieczan 2009). Propolis seems to be an effective natural alternative to antibiotic growth promoters. Research results (Li \& Zhang 2002, Roodsari et al. 2004, Zeng et al. 2004) suggest that propolis has a beneficial influence on daily gains, feed intake and 
conversion in different animal species, including poultry. In a study by Roodsari et al. (2004), chickens fed $250 \mathrm{mg}$ propolis perkg feed were characterized by significantly higher body weights and lower feed intake perkg body weight gain, compared with birds receiving diets without propolis supplements. In an experiment by Zeng et al. (2004), a combination of flower pollen and propolis at a ratio of 2.5:1 used as a feed additive increased the body weights of chickens by nearly $10 \%$ in comparison with the control group. Li \& Zhang (2002) reported that supplementing diets for broiler chickens with $2.5 \%$ propolis contributed to higher weight gains and better feed conversion, thus increasing production profitability by $9.7 \%$.

The adverse effect of broiler selection programs that focus on increased body weight and a faster growth rate is a higher incidence of leg problems, in particular bone deformities and abnormalities (Leterrier \& Nys 1992, Horn 2000, Williams et al. 2004). The skeletal system plays many important functions: it keeps the body in an upright position, it is responsible for body locomotion, it protects organs and tissues, and it serves as the main storage system for mineral compounds, mostly calcium, phosphorus and magnesium (Toba et al. 2000). According to Stójko et al. (1978), an ethanol extract of propolis accelerates the healing of bone fractures. Ang et al. (2009) have recently demonstrated that a bioactive component of propolis, caffeic acid phenethyl ester (CAPE), has very strong properties supporting the growth and development of human bones. According to the cited authors, CAPE is a potential treatment for bone lytic diseases, and a therapeutic agent for osteoporosis. Propolis has been also found to significantly improve the availability and utilization of dietary calcium and phosphorus, which has a beneficial effect on the skeleton (Haro et al. 2000).

Various studies show that propolis positively affects chicken performance, yet scientific literature provides scant information on the effects of propolis on bone strength in birds. In view of the above, the objective of this study was to determine the effect of diet supplementation with propolis and bee pollen on the physical, biomechanical and chemical properties of tibial bones in broiler chickens.

\section{Materials and methods}

The experimental materials comprised 384 Ross 308 chickens (four groups, three replications), divided into groups of males and females, and raised to 35 days of age. The birds were fed ad libitum starter, grower and finisher diets, from day 1 to 14 , from day 15 to 28 and from day 29 to 35 , respectively (Table 1). Control group (1) birds were fed a commercial diet throughout the experiment. Birds of three experimental groups received, for the first two weeks of rearing, standard diets with a different content of propolis and/or bee pollen:

- group $2-0.025 \%$ propolis,

- group 3 - $0.5 \%$ bee pollen,

- group 4 - $0.5 \%$ bee pollen and $0.025 \%$.

Propolis dry extract standardized to contain $5 \%$ quercetin was purchased ay Phytopharm Klęka (Poland). Dry bee pollen was supplied from an apiary of the Department of Apiculture, Faculty of Animal Bioengineering, University of Warmia and Mazury in Olsztyn, Poland. Propolis and bee pollen, in powder form, were mixed with dry feed. 
Table 1

Nutritive value of diets

\begin{tabular}{lccc}
\hline Nutrients & Starter & $\begin{array}{c}\text { Diet } \\
\text { Grower }\end{array}$ & Finisher \\
\hline Energy, kcal & 2950 & 3040 & 3120 \\
Total protein, \% & 21.4 & 20.2 & 19.8 \\
Lysine, \% & 1.35 & 1.25 & 1.2 \\
Methionine+cystine, \% & 0.96 & 0.92 & 0.92 \\
Threonine, \% & 0.78 & 0.82 & 0.76 \\
Clcium, \% & 0.80 & 0.80 & 0.82 \\
Available phosphorus, \% & 0.42 & 0.40 & 0.37 \\
Sodium, \% & 0.16 & 0.17 & 0.17 \\
Vitamin A, IU & 15000 & 12000 & 12000 \\
Vitamin $\mathrm{D}_{3^{\prime}}$ IU & 3750 & 3000 & 3000 \\
Vitamin , mg & 52 & 41 & 41 \\
Crude fiber, \% & 3.0 & 3.1 & 3.4 \\
Coccidiostat salinomycin, ppm & 60 & 60 & - \\
\hline
\end{tabular}

At the completion of the experiment, 12 chickens (69 and $\left.60^{\circ}\right)$ randomly selected of each group were fasted for $12 \mathrm{~h}$, weighed and sacrificed. The carcasses (after the removal of head and feet, and evisceration) were chilled at $+4^{\circ} \mathrm{C}$ for $18 \mathrm{~h}$, weighed and dissected. Tibial bones were separated, removing cartilage. The weight, length and mid-shaft circumference of the tibia were determined.

Mid-shaft shear strength was measured using an Instron universal testing machine 4301 (Instron, Norwood, MA, USA), coupled to a computer to obtain force-deformation curves illustrating the correlation between shear force perpendicular to the long axis of the bone and deformation. Load values were recorded at a constant speed $(\mathrm{V}=10 \mathrm{~mm} / \mathrm{min})$ of a single cutting blade (Warner-Bratzler Shear, type 2830-013). Force capacities ranged from 0 to $1000 \mathrm{~N}$. The measurements were performed in 12 replications per sample (variant), at room temperature. The data were analyzed using Instron Series IX Instron Series IX Software 8.34.00 (Instron, Norwood, MA, USA)

Bone strength was determined according to the method proposed by Szeremeta et al. (2003), based on the following measurements: shear force $F_{1}(N)$ needed to break the bone, the maximum shear force (intersection point, $\mathrm{F}_{\text {max }} \mathrm{N}$ ) needed for bone disintegration and interruption of the bone structure, and bone deformation in response to the maximum shear force $\left(d_{\text {max }^{\prime}} m m\right)$. Bone stiffness was calculated as the $F_{\text {max }}$ to $d_{\text {max }}$ ratio $(\mathrm{N} / \mathrm{mm})$.

The geometric parameters of the bones, determined after a mid-shaft shear test, included vertical (A) and horizontal (B) external diameters, vertical (C) and horizontal (D) internal diameters. The measurements were taken with an electronic caliper. Based on the geometric characteristics of the tibia, the following parameters were determined as described by Brzóska et al. (2005):

- Cortical thickness (mm) B - D

- Cortical index (B - D)/B $\times 100$

- Cortical area $\left(\mathrm{mm}^{2}\right) B^{2}-D^{2}$

- Cortical area ratio $\left(B^{2}-D^{2}\right) / B^{2} \times 100$

- Cross-sectional moment of inertia (CSMI) $3.14\left(A^{3} B-C^{3} D\right) / 64$ 
- Cross-sectional area (CSA) $\left(\mathrm{mm}^{2}\right) 3.14(\mathrm{BA}-\mathrm{DC}) / 4$

- Mean relative wall thickness (MRWT) $[(A-C) / C+(B-D) / D] / 2$

The content of crude ash and minerals (calcium and phosphorus) in tibial bones was determined after dry mineralization at $650^{\circ} \mathrm{C}$. Ca content was measured by spectrophotometry, and $\mathrm{P}$ content was estimated colorimetrically. Bone samples were mineralized in a mixture of nitric acid and perchloric acid (3:1) (Merck, Darmstadt, Germany). Mineralization was carried out in an aluminum heating block with temperature control (VELP DK 20, VELP Scientifica, Usmate, Italy). Reference samples were prepared together with test samples. The Ca content of mineralizates was determined by flame atomic absorption spectrometry (acetylene-air flame), with the use of Unicam 939 atomic absorption spectrometer (Solar, Cambridge, UK), equipped with an Optimus data station, a background correction source (deuterium lamp) and cathode lamps (Whiteside \& Miner 1984). In order to determine Ca content, a $10 \%$ aqueous solution of lanthanum chloride was added to all experimental solutions, in the amount ensuring the final $\mathrm{La}^{+3}$ concentration of $1 \%$. Phosphorus concentration was determined in mineralizates by colorimetry with ammonium molybdate and with sodium sulfate and hydroquinone. Absorbance was measured using a VIS 6000 spectrophotometer (A. KRÜSS Optronic GmbH, Hamburg, Germany), at a wavelength of $\lambda=610 \mathrm{~nm}$ (Fiske \& Subbarow 1925). The content of $\mathrm{Ca}$ and $\mathrm{P}$ was determined using standards at a concentration of $1 \mathrm{mg} / \mathrm{cm}^{3}$, diluted with a 0.1 M solution of $\mathrm{HNO}_{3}$ (BDH Prolabo, VWR International GmbH, Darmstadt, Germany).

The obtained results were processed statistically (means, standard deviations SD), and the significance of differences between mean values in experimental groups was estimated in males and females (two-way ANOVA) (Statistica 8, StatSoft, Inc. Tulsa, OK, USA).

\section{Results and discussion}

The weight and length of tibial bones and their percentage share of total body weight were similar in all groups of broilers. The values of the above parameters were affected by gender - the bones of males were heavier and longer than the bones of females (Table 2), which is consistent with the findings of Szeremeta et al. (2005).

The data in Table 3 show that group 4 chickens, fed a diet supplemented with $0.5 \%$ bee pollen and $0.025 \%$ propolis, were characterized by higher values of the geometric parameters of the tibia (cortical thickness, cortical index, cortical area ratio, mean relative wall thickness), compared with the other groups. Cortical thickness, cortical area, cross-sectional moment of inertia and cross-sectional area were significantly higher in males than in females (Table 3). According to Rath et al. (1999), such differences may be due to a different mode of action of male and female sex hormones.

In poultry, bone strength is affected by numerous factors, including nutritional regime, genetic factors, sex, age, management conditions and production system. Recent years have witnessed an increasing interest in the use of various feed additives and dietary supplements believed to improve skeletal integrity in poultry, such as phytase, herbs and ascorbic acid (Kocabagli 2001, Kwiecień, Winiarska-Mieczan 2009, Yildiz et al. 2009). An analysis of the biomechanical properties of the tibia in broiler chickens revealed that propolis and bee pollen did not lead to significant differences in the values of shear force, maximum shear force, bone deformation caused by the maximum shear force, and bone stiffness (Table 4). It is difficult 
to compare the current results with the findings of other authors since the available scientific literature provides no relevant information.

Table 2

Physical properties of the tibia in broiler chickens

\begin{tabular}{lccccccc}
\hline Specification & Statistical & \multicolumn{3}{c}{ Group } & \multicolumn{2}{c}{ Gender } \\
& measures & 1 & 2 & 3 & 4 & $0^{*}$ & \% \\
\hline Tibia weight, g & mean & 22.71 & 22.56 & 23.29 & 22.15 & $25.67^{* *}$ & 19.68 \\
& SD & 2.20 & 2.08 & 1.84 & 1.62 & 1.35 & 0.93 \\
Tibia length, mm & mean & 93.0 & 92.4 & 92.1 & 92.2 & $93.4^{* *}$ & 91.4 \\
& SD & 2.5 & 3.2 & 1.8 & 1.3 & 2.3 & 1.8 \\
Tibia percentage in the & mean & 1.01 & 1.06 & 1.04 & 1.00 & $1.07^{* *}$ & 0.98 \\
total body weight, $\%$ & SD & 0.09 & 0.08 & 0.09 & 0.07 & 0.07 & 0.07 \\
\hline
\end{tabular}

${ }^{* *} P \leq 0.01$

Table 3

Geometric characteristics of the tibia in broiler chickens

\begin{tabular}{|c|c|c|c|c|c|c|c|}
\hline \multirow[t]{2}{*}{ Specification } & \multirow{2}{*}{$\begin{array}{l}\text { Statistical } \\
\text { measures }\end{array}$} & \multicolumn{4}{|c|}{ Group } & \multicolumn{2}{|c|}{ Gender } \\
\hline & & 1 & 2 & 3 & 4 & $0^{\pi}$ & @ \\
\hline \multirow[t]{2}{*}{ Cortical thickness, mm } & mean & $3.26^{\mathrm{ABab}}$ & $2.86^{\mathrm{Bb}}$ & $3.05^{\mathrm{ABb}}$ & $3.56^{\mathrm{Aa}}$ & $3.50 * *$ & 2.87 \\
\hline & SD & 0.90 & 0.47 & 0.58 & 0.63 & 0.64 & 0.61 \\
\hline \multirow[t]{2}{*}{ Cortical index } & mean & $39.75^{\mathrm{AB}}$ & $36.17^{B}$ & $36.37^{B}$ & $44.55^{\mathrm{A}}$ & 39.97 & 38.45 \\
\hline & SD & 8.17 & 5.70 & 5.12 & 6.91 & 6.16 & 8.23 \\
\hline \multirow[t]{2}{*}{ Cortical area, $\mathrm{mm}^{2}$} & mean & 42.76 & 37.26 & 41.94 & 44.45 & $48.84^{* *}$ & 34.36 \\
\hline & SD & 13.72 & 7.75 & 10.68 & 10.06 & 9.12 & 6.63 \\
\hline \multirow[t]{2}{*}{ Cortical area ratio } & mean & $63.08^{\mathrm{AB}}$ & $58.96^{\mathrm{B}}$ & $59.27^{\mathrm{B}}$ & $68.81^{\mathrm{A}}$ & 63.60 & 61.47 \\
\hline & SD & 10.15 & 7.31 & 6.65 & 7.61 & 7.05 & 10.23 \\
\hline \multirow{2}{*}{$\begin{array}{l}\text { Cross-sectional moment } \\
\text { of inertia CSMI }\end{array}$} & mean & 178.07 & 180.93 & 219.98 & 202.00 & $247.18^{* *}$ & 143.31 \\
\hline & SD & 101.31 & 60.38 & 106.45 & 83.69 & 95.14 & 36.67 \\
\hline Cross-sectional area & mean & 32.59 & 31.22 & 34.16 & 36.18 & $38.71^{* *}$ & 28.37 \\
\hline $\mathrm{CSA}, \mathrm{mm}^{2}$ & SD & 9.08 & 5.91 & 9.26 & 7.59 & 7.29 & 4.78 \\
\hline \multirow{2}{*}{$\begin{array}{l}\text { Mean relative wall } \\
\text { thickness MRWT }\end{array}$} & mean & $0.71^{\mathrm{ABa}}$ & $0.63^{\mathrm{Aa}}$ & $0.63^{\mathrm{Aa}}$ & $0.86^{\mathrm{Bb}}$ & 0.74 & 0.68 \\
\hline & SD & 0.19 & 0.09 & 0.13 & 0.14 & 0.16 & 0.17 \\
\hline
\end{tabular}

${ }^{*} P \leq 0.01, \quad{ }^{A B} P \leq 0.01, \quad$ ab $P \leq 0.05$

Table 4

Strength parameters of the tibia in broiler chickens

\begin{tabular}{|c|c|c|c|c|c|c|c|}
\hline \multirow[t]{2}{*}{ Specification } & \multirow{2}{*}{$\begin{array}{l}\text { Statistical } \\
\text { measures }\end{array}$} & \multicolumn{4}{|c|}{ Group } & \multicolumn{2}{|c|}{ Gender } \\
\hline & & 1 & 2 & 3 & 4 & $0^{\prime \prime}$ & 운 \\
\hline \multirow{2}{*}{$\begin{array}{l}\text { Shear force } \\
\mathrm{F}_{1}, \mathrm{~N}\end{array}$} & mean & 413.88 & 378.38 & 379.90 & 375.88 & $420.93^{* *}$ & 353.09 \\
\hline & SD & 101.34 & 99.52 & 78.04 & 87.27 & 83.82 & 85.34 \\
\hline \multirow{4}{*}{$\begin{array}{l}\text { Maximum shear force } \\
\mathrm{F}_{\text {max }}, \mathrm{N} \\
\text { Deformation } \mathrm{d}_{\text {max }} \text { in } \\
\text { response to the maximum } \\
\text { shear force, } \mathrm{mm}\end{array}$} & mean & 445.48 & 395.37 & 386.48 & 386.97 & $436.54^{*}$ & 370.61 \\
\hline & SD & 115.69 & 121.88 & 74.79 & 75.97 & 104.01 & 84.27 \\
\hline & mean & 3.70 & 2.64 & 3.35 & 3.23 & 2.77 & 3.69 \\
\hline & SD & 1.89 & 1.46 & 1.97 & 2.17 & 1.35 & 2.21 \\
\hline \multirow[t]{2}{*}{ Stiffness $\mathrm{F}_{\max } / \mathrm{d}_{\max } \mathrm{N} / \mathrm{mm}$} & mean & 2.12 & 2.21 & 2.11 & 2.14 & $2.23^{*}$ & 2.06 \\
\hline & SD & 11.76 & 9.05 & 11.06 & 13.87 & 8.77 & 12.64 \\
\hline
\end{tabular}

${ }^{*} P \leq 0.01,{ }^{*} P \leq 0.05$ 
Bone strength values, including shear force needed to break the bone $\left(\mathrm{F}_{10}=420.93 \mathrm{~N}\right.$, $\left.\mathrm{F}_{19}=353.09 \mathrm{~N}\right)$ and the maximum shear force $\left(\mathrm{F}_{\max 0}=436.54 \mathrm{~N}, \mathrm{~F}_{\max 9}=370.61 \mathrm{~N}\right)$, were higher in males than in females (Table 4). As reported by Frost (1997), bone strength is directly proportional to bone mass. This correlation was also observed in the present study - the tibial bones of males were both heavier and stronger than the tibias of females.

The highest content of dry matter was noted in the tibial bones of broilers fed a diet supplemented with propolis and bee pollen (group 4). Phosphorus concentrations in the tibial bones of chickens were comparable in all groups. Concentrations of calcium in ash was highest in the tibial bones of broilers in the control group and group 4, fed a diet supplemented with $0.5 \%$ bee pollen and $0.025 \%$ propolis. In the other groups the level of calcium was significantly lower. The chemical composition of the tibia was similar in males and females (Table 5).

Table 5

Mineral composition of the tibia in broiler chickens

\begin{tabular}{|c|c|c|c|c|c|c|c|}
\hline \multirow[t]{2}{*}{ Percentage share } & \multirow{2}{*}{$\begin{array}{l}\text { Statistical } \\
\text { measures }\end{array}$} & \multicolumn{4}{|c|}{ Group } & \multicolumn{2}{|c|}{ Gender } \\
\hline & & 1 & 2 & 3 & 4 & $0^{\prime \prime}$ & \% \\
\hline \multirow[t]{2}{*}{ Tibia dry matter } & mean & $94.96^{\mathrm{ab}}$ & $94.46^{b}$ & $94.69^{a b}$ & $95.34^{\mathrm{a}}$ & 94.72 & 95.01 \\
\hline & SD & 0.62 & 0.81 & 0.99 & 0.72 & 0.79 & 0.86 \\
\hline \multirow[t]{2}{*}{ Ash in tibia dry matter } & mean & 54.38 & 55.16 & 54.57 & 54.07 & 54.37 & 54.72 \\
\hline & SD & 1.69 & 2.53 & 1.92 & 2.57 & 1.90 & 2.45 \\
\hline \multirow[t]{2}{*}{ Phosphorus in ash } & mean & 17.02 & 17.00 & 17.18 & 17.02 & 16.99 & 17.12 \\
\hline & SD & 0.30 & 0.67 & 0.70 & 0.43 & 0.46 & 0.61 \\
\hline \multirow[t]{2}{*}{ Calcium in ash } & mean & $38.86^{\mathrm{a}}$ & $37.86^{b}$ & $37.99^{b}$ & $38.18^{\mathrm{ab}}$ & 38.46 & 37.98 \\
\hline & SD & 1.05 & 0.79 & 1.22 & 0.40 & 0.90 & 1.00 \\
\hline
\end{tabular}

Means followed by small letters are significantly different at $P \leq 0.05$

In conclusion, higher values of geometric parameters were noted in the tibial bones of broilers fed a diet supplemented with a combination of propolis and bee pollen, in comparison with birds fed diets containing propolis or bee pollen administered alone. The shear strength values and physical properties of bones were similar in all groups. In view of the positive effect of the analyzed dietary supplements on the geometric parameters and chemical properties of the tibia in broiler chickens, further research is needed to determine the optimal dosage of propolis and bee pollen fed to poultry.

\section{References}

Ang ES, Pavlos NJ, Chai YL, Qi M, Cheng TS, Steer JH, Joyce DA, Zheng MH, Xu J (2009) Caffeic acid phenethyl ester an active component of honeybee propolis attenuates osteoclastogenesis and bone resorption via the suppression of RANKL-induced NF-KB and NFAT activity. J Cell Physiol 221, 642-649

Brzóska MM, Majewska K, Moniuszko-Jakoniuk J (2005) Mechanical properties of femoral diaphysis and femoral neck of female rats chronically exposed to various levels of cadmium. Calcif Tissue Int 76, 287-298

Fiske CH, Subbarow Y (1925) The colorimetric determination of phosphorus. J Biol Chem 66, 375-400

Frost HM (1997) Obesity and bone strength, and mass: A tutorial based on insight from new paradigm. Bone $21,211-214$ 
Haro A, López-Aliaga I, Lisbona F, Barrionuevo M, Alférez MJ, Campos MS (2000) Beneficial effects of pollen and/or propolis on the metabolism on iron, calcium, phosphorus and magnesium in rats with nutritional ferropenic anemia. J Agric Food Chem 48, 5715-5722

Horn P (2000) [Breeding and management aspects of broiler production]. Arch Tierz 43 Special Issue, 106-110 [in German]

Kocabagli N (2001) The effect of dietary phytase supplementation at different levels on tibial bone characteristics and strength in broilers. Turk J Vet Anim Sci 25, 797-802

Kwiecień M, Winiarska-Mieczan A (2008) [Changes of bone parameters of chickens fed a descreased energy value feed mixture]. Med Weter 64, 480-483 [in Polish]

Kwiecień M, Winiarska-Mieczan A (2009) Effect of addition of herbs on body weight and assessment of physical and chemical alterations in the tibia bones of broiler chickens. J Elementol 14, 705-715

Li Z, Zhang Z (2002) Effects of ration supplemented with propolis on liveweight gain of broilers. China Poult 24,22

Leterrier C, Nys Y (1992) Composition, cortical structure and mechanical properties of chicken tibiotarsi: effect of growth rate. Br Poult Sci 33, 925-939

Rath NC, Balog JM, Huff WE, Huff GR, Kulkarni GB, Tierce JF (1999) Comparative differences in the composition and biochemical properties of tibiae of seven- and seventy-two-week old male and female broiler breeder chickens. Poult Sci 78, 1232-1032

Roodsari MH, Mehdizadeh M, Kasmani FB, Lotfelahian H, Mosavi F, Abolghasemi AH (2004) Effects of oilextracted propolis on the performance of broiler chicks. Agric Sci Technol 18, 57-65

Stójko A, Scheller S, Szwarnowiecka I, Tustanowski J, Ostach H, Obuszkoz (1978) Biological properties and clinical application of propolis. VIII. Experimental observation on the influence of ethanol extract of propolis (EEP) on the regeneration of bone tissue. Arzneimittelforschung 28, 35-37

Szeremeta J, Wawro K, Majewska K, Kleczek K (2003) The effect of ad libitum and quantitatively restricted feeding on bone breaking strength in chickens. Pol J Nat Sci 14, 431-438

Szeremeta J, Bochno R, Murawska D (2005) Effects of type, age and sex of chickens on the physical and mechanical properties and mineral composition of leg bones. Pol J Nat Sci 18, 94-103

Toba Y, Kajita Y, Masuyama R, Takada Y, Suzuki K, Aoe S (2000) Dietary magnesium supplementation affects bone metabolism and dynamic strength of bone in ovariectomized rats. J Nutr 130, 216-220

Whiteside P, Miner B (1984) Pye Unicam Atomic Absorption Data Book. Pye Unicam LTD, Cambridge, UK

Williams B, Waddington D, Murray DH, Farquharson C (2004) Bone strength during growth: influence of growth rate on cortical porosity and mineralization. Calcif Tissue Int 74, 236-245

Yildiz H, Gunes N, Gezen SS, Ozcan R, Petek M, Yilmaz B, Arican I (2009) Effect of ascorbic acid and lighting schedule on tibiotaurus strength and bone characteristics in broilers. Arch Tierz 52, 432-444

Zeng Z, Liu S, Pan K, Wu H, Tang K (2004) Effects of pollen and propolis on productive and immune performance in meat fowl. Sci Agric Sin 37, 751-755

Zimnoch L, Szarek J, Abczak J, Konwicki A (2000) Effects of feed supplements on morphological pattern of internal organs in broiler chickens. Zesz Nauk PTZ Prz Hod 49, $65-76$ [in Polish]

Received 24 May 2011, accepted 31 August 2011.

Corresponding author:

Katarzyna Kleczek

email: katarzyna.kleczek@uwm.edu.pl

Department of Commodity Science and Animal Improvement, Faculty of Animal Bioengineering University of Warmia and Mazury, ul. Oczapowskiego 5, 10-718 Olsztyn, Poland 